\title{
Avocado leaf extract activates Adenosine Deaminase (ADA) in Larynx cancer tissues
}

\section{Avokado yaprağı ekstresinin Larinks kanseri dokularında Adenozin Deaminaz (ADA) üzerine aktive edici etkisi}

\author{
Ayça Ant ${ }^{1}$, Aslıhan Avcr ${ }^{3}$, Metin Genç ${ }^{3}$, Erdoğan İnal ${ }^{1}$, Ümit Tunçel ${ }^{2}$, Ziya Şencan ${ }^{2}$ \\ ${ }^{1}$ Department Of Otorhinolaryngology, Faculty Of Medicine, Gazi University, Besevler, Ankara, Turkey \\ ${ }^{2}$ Department Of Otorhinolaryngology, Ankara Oncology Education And Research Hospital, Yenimahalle, \\ Ankara, Turkey \\ ${ }^{3}$ Department Of Biochemistry, Faculty Of Medicine, Ankara University, Cebeci, Ankara, Turkey
}

\section{ÖZET}

GíRIŞ ve AMAÇ: Adenozin deaminaz (ADA), pürin ve DNA metabolizmasına katılan ve serbest oksijen radikali (SOR) oluşumunun mekanizmasında yer alan anahtar bir enzimdir. Araştırmalar, avokadonun kanser önleyici özelliklerinden birinin ağırlıklı olarak SOR üretimi sonucu olduğunu göstermektedir. Bu çalışmada amacımız, Avokado yaprağı ektresinin, kanserli ve kanserli olmayan larinksdokularında ADA'nın aktivite seviyesine olası etkilerinin araştırılmasıdır.

YÖNTEM ve GEREÇLER: On üç hastanın larinks karsinom dokusunun ADA aktiviteleri, Avokado yaprak ekstreli ve ekstresiz, tümörlü ve tümörsüz kontrol dokuları ile karşılaştırılarak, fark açısından değerlendirildi.

BULGULAR: ADA aktivitesi kanserli dokularda kanserli olmayan kontrol dokularına göre anlamlı olarak artmıştır ( $\mathrm{p}<0.001)$. Avokado yaprak ekstresi, kanserli dokulardaki ADA aktivitelerini $(\mathrm{r}=0.93, \mathrm{p}<0.001)$ kanserli olmayan $(r=0.60, p=0.029)$ dokudan daha fazla arttırmıștır.

TARTIŞMA ve SONUÇ: ADA enzim aktivitesinin yüksekliği, substratlarının (adenozin ve deoksiadenozin) toksik birikimine karşı telafi edici bir mekanizma şeklinde açıklanabilir. Bu durumda Avokado yaprağı ekstresi, kanserli dokularda larenks kanseri olmayan dokulara kıyasla daha yüksek ADA aktivitesine yol açarak bu toksik birikimi engelleyebilir.

Anahtar Kelimeler: Adenozin deaminaz, avokado, diyet, kanser, larinks

\begin{abstract}
INTRODUCTION: Adenosine deaminase (ADA) is a key enzyme that participate in purine and DNA metabolism and one of the central mechanism of free oxygen radical (FOR) formation. Studies have indicated that, one of the cancer-preventing properties of avocado occurs mainly by FOR production. Our aim in this study is to investigate possible potential effects of the aqueous extract of Avocado leaf on the activity level of ADA in cancerous and non-cancerous tissues of larynx for elucidation of the molecular mechanism.
\end{abstract}

MATERIALS and METHODS: The ADA activities of the larynx carcinoma tissues of thirteen patients were compared with the adjacent tumor-free control tissues with and without Avocado leaf extract were evaluated in terms of difference.

RESULTS: The ADA activities were significantly increased in cancerous tissues compared with the noncancerous control tissues $(\mathrm{p}<0.001)$. The extract of avocado leaf increased the ADA activities in cancerous tissues $(\mathrm{r}=0.93, \mathrm{p}<0.001)$ more than noncancerous $(\mathrm{r}=0.60, \mathrm{p}=0.029)$ tissues significantly.

CONCLUSIONS: Our results can be explained as elevated ADA enzyme activity is a compensatory mechanism against toxic accumulation of its substrates (adenosine and deoxyadenosine) and Avocado activates ADA actitvity in cancerous tissues higher than non-cancerous tissues of larynx.

Keywords: Adenosine deaminase, avocado, cancer, diet, larynx 


\section{INTRODUCTION}

Laryngeal cancer (LC) is the second most common malignancy of the upper aerodigestive tract (UADT) and $85-95 \%$ of laryngeal malignancies are squamous cell carcinoma (SCC) that arises from the epithelial lining of the larynx. Risk factors for the development of SCC of the larynx are tobacco, alcohol, laryngopharyngeal reflux, diet, occupational toxins, HPV and genetic susceptibility (1). Diet is a substantial risk factor especially for all UADT malignancies, including LC. The protective effects of fruit and vegetables in diet are predicted to be associated with the potentially cancer preventing phytochemicals (2). Despite the significant improvements in the treatment of cancer, especially in case of the late stages of cancer as well as LC, increasing morbidity and mortality have encouraged extensive research on the chemoprevention with phytochemicals of medicinal plants. Pro-oxidant and anticancer activities of medicinal plants represent natural products that might be used as cancer chemotherapeutic agents $(3,4)$.

The avocado (Persea americana Mill., Lauracea) is the widely investigated fruit with its meat, leaf and seed in medical therapy for many diseases including cancer. The healthy properties of avocado are thought to be owing to its content of mono- and polyunsaturated fats, essential nutrients and phytochemicals (2). Some evidence of cancer chemopreventive properties of Persea americana has been described in the literature. Studies in different types of cancer have indicated that, these properties of avocado occurs mainly by means of inhibition of cell growth, inducing apoptosis associated with free oxygen radical (FOR) production and selectively eliminating cancer cells from normal cells $(2,4-9)$. However the cellular and molecular mechanisms of the cancer chemopreventive phytochemicals of avocado are largely unknown, no data are available whether avocado has any effect on laryngeal cancer tissues.

Adenosine deaminase (ADA) is a key enzyme that participate in purine and DNA metabolism and needed for the turnover of nucleic acids in tissues. ADA, designated as E.C. 3.5.4.4., irreversibly converts adenosine or deoxyadenosine to inosine or deoxyinosine and ammonia. This enzyme is also shown as one of the central mechanism of FOR formation (10). Since ADA anticancer therapy is investigational and recommended therapy for solid tumors (11), the research question of this study is whether Avocado leaf extract affect ADA activity in laryngeal cancer tissues. Our aim in this study is to investigate possible potential effects of the aqueous extract of Avocado leaf on the activity level of ADA in cancerous and non-cancerous tissues of larynx for elucidation of the molecular mechanism.

\section{MATERIALS and METHODS}

\section{Cases}

This study consisted of thirteen patients who underwent surgery for larynx cancer (median age of 57 years, range: 40-67) in ENT Departments of two tertiary referral centers. All patients were histologically diagnosed by incisional biopsy prior to surgical procedures. None of the patients had a history of prior radiotherapy and/or chemotherapy. All patients were staged by the TNM classification [American Joint Committee on Cancer (AJCC)]. The approval was taken from the institutional research committee (GU117) and informed consents were obtained from the patients.

\section{Samples}

Surgical resection was performed on all patients under general anestesia. After the surgical resection, tumor and adjacent tumorfree samples from larynx tissue (which are confirmed histologically) with 1-2 mm diameter were put immediately in eppendorf tubes (with 1-2 cc of $0.9 \%$ saline) and transferred in liquid nitrogen to the biochemistry laboratory, where the samples were preserved for 3 months at $-80^{\circ} \mathrm{C}$ temperature until the time of analysis.

\section{Preparation of the aqueous extract of plant (avocado leaf)}

Fresh avocado leaves ( $5 \mathrm{gr}$ ) were washed with distilled water, homogenized and incubated in $100 \mathrm{ml}$ ethyl alcohol $(5 \% \mathrm{v} / \mathrm{v})$ for three hours on vortex at room temperature. Following the incubation, it was centrifuged at $4000 \mathrm{rpm}$ for 10 minutes at room temperature. Upper clear layer was used as the aqueous extract of avocado leaf in the experiments (8).

\section{Biochemical measurements}

On the analysis day, the tissues were first washed with deionized water to separate blood 
then homogenized in a homogenizator (Heidolph DIAX 900 model; Heidolph Instruments GmbH \& Co. KG, Scwabach, Germany). The upper clear layer was taken to be used in the assays after centrifugation at $5000 \mathrm{~g}$ for about 20 minutes. The supernatants of tissue homogenates $(25 \mu l)$ were preincubated with the extract $(25 \mu \mathrm{l})$ for 30 minutes. Then, ADA activity was measured with and without the extract and the results were expressed as $\mathrm{mIU} / \mathrm{mg}$.

\section{Measurements of ADA activity}

ADA activity was measured spectrophotometrically by Guisti method (12) which is based on the direct measurement of the ammonia and the results were expressed as miliunit per miligram (mIU/mg).

\section{Statistical analysis}

The correlation between age, gender, smoking and alcohol usage, stages of clinical and pathological TNM parameters and the enzyme activity levels were studied. Statistical analysis was performed with SPSS for Windows, Version 15.0. Chicago, SPSS Inc. The continuous variables were evaluated by visual (Histogram) and statistical methods (ShapiroWilk and Kolmogorov and Smirnov Tests) and it was seen that the data did not follow normal distribution. Thus non parametric tests were used. The results were evaluated statistically by using nonparametric tests as Wilcoxon Signed Ranks Test and Spearman Correlation Analysis Test with statistical significance being accepted at 0.05 .

\section{RESULTS}

The distribution of localization and differentiation of larynx (squamous cell) carcinoma of the patients are given in Table 1. Smoking habit was determined in $92 \%(\mathrm{n}=12)$ of the patients and the habit of alcohol usage was $38 \%(n=5)$.

Clinical and pathological TNM staging were done pre- and post-operatively. The agreement between clinical and pathological staging was assessed as significant (Cohen's kappa $=1,00 / \mathrm{p}<0.001)$.

The numbers and percentages of clinical and pathological TNM staging of the patients are given in Table 1.

The ADA activities were significantly increased in cancerous tissues compared with the noncancerous control tissues $(\mathrm{p}<0.001)$
(Table 2). The extract of avocado leaf increased the ADA activities in cancerous tissues $(\mathrm{r}=0.93, \quad \mathrm{p}<0.001)$ more than noncancerous $\quad(\mathrm{r}=0.60, \quad \mathrm{p}=0.029)$ tissues significantly (Table 3). There was no correlation between ADA enzyme activity in the cancerous and noncancerous tissues with and without extracts and the degree of differentiation $(p>0.05)$.

\section{DISCUSSION}

Various plant parts and chemical constituents of Avocado (Persea americana Mill., Lauracea) are shown to have anticancer activities on cancer cells in in vitro and animal studies (2,4-9). In a study by Ding et al. it has been reported that the phytochemicals extracted from avocado meat into a chloroform partition (D003) selectively induced apoptosis in human oral cancer cell lines but not normal (2). Subsequent study of Ding et al. it was stated that the treatment of human oral cancer cell lines containing high levels of ROS with D003 increased ROS levels twofold to threefold and induced apoptosis. However in the normal cell lines with lower levels of basal ROS, levels of ROS increased only 1.3 fold, and apoptosis was not induced. N-acetyl- 1cysteine (NAC) application reducing ROS levels converted malignant cell lines resistant to D003 induced apoptosis. Precancerous human oral epithelial cell lines transformed with HPV16 also expressed higher basal levels of ROS and became sensitive to D003. They stated that perturbing the ROS levels in human oral cancer cell lines may be a key factor in selective apoptosis and molecular targeting for chemoprevention by phytochemicals (8). In another study with oral cancer cell lines, it was shown that the growth inhibitory efficacy of the chloroform extract was due to blocking the phosphorylation of EGFR (Tyr1173), c-RAF (Ser338), and ERK1/2 (Thr202/Tyr204) in the EGFR/RAS/RAF/MEK/ERK1/ 2 cancer pathway. They suggested that the potential anticancer activity of avocado fruits was due to a combination of specific aliphatic acetogenins that target components of the EGFR/RAS/RAF/MEK/ERK1/2 cancer pathway (9). 
Table 1: The percentage and number of localization, differentiation and pathological tumor, nodal and metastasis stage (according to the TNM staging system) of the cases with LC.

Localization

Supraglottic

Glottic

\section{Differentiation}

Low The percentage of the cases

The number of the cases

$62 \%$

8

$38 \%$

5

Moderate

$46.2 \%$

6

High

$23 \%$

3

\section{Tumor Stage}

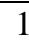

$15.3 \%$

2

2

$38.5 \%$

5

3

$7.7 \%$

$38.5 \%$

5

\section{Nodal Stage}

\begin{tabular}{lll}
\hline 0 & $38.5 \%$ & 5 \\
1 & $15.3 \%$ & 2 \\
2 & $38.5 \%$ & 5 \\
\hline
\end{tabular}

\begin{tabular}{lcc}
\hline Distant Metastasis Stage & \\
\hline 0 & $100 \%$ & 13 \\
1 & $0 \%$ & 0 \\
\hline Total & $100 \%$ & 13 \\
\hline
\end{tabular}

Adress for correspondence: Sağlık Bilimleri Üniversitesi Ankara Abdurrahman Yurtaslan Onkoloji Eğitim Ve Araștırma Hastanesi Demetevler Yenimahalle 
Table 2: The assessment of the activity of ADA between normal $(\mathrm{N})$ and tumor $(\mathrm{T})$ tissue (Statistical analysis with the Wilcoxon Signed Ranks Test):

\begin{tabular}{llll}
\hline & $\begin{array}{l}\text { The median value }(\text { min- } \\
\text { max }) \text { of ADA activity in } \\
\text { normal tissue }(\mathrm{N})(\mathrm{mIU} \\
\left.\mathrm{mg}^{-1}\right)\end{array}$ & $\begin{array}{l}\text { The median value }(\min -\mathrm{max}) \text { of ADA } \\
\text { activity in tumor tissue }(\mathrm{T})\left(\mathrm{mIU} \mathrm{mg}^{-1}\right)\end{array}$ & $\begin{array}{l}\text { The difference between } \\
\text { the medians of the } \\
\text { activities } \\
(\mathrm{N}-\mathrm{T})\left(\mathrm{mIU} \mathrm{mg}^{-1}\right)\end{array}$ \\
\hline ADA & $2.68(0.44-16.21)$ & $20.49(5.68-38.27)$ & $-17.81 \quad \mathrm{p}<0.001$
\end{tabular}

Table 3: The assessment of the correlation between the activity of ADA of the normal (N) and tumor (T) tissues with and without Avocado leaf extract. (Statistical analysis with the Spearman Correlation Analysis Test):

The Correlation between ADA activity (Pure tissue/Tissue with Correlation Coefficient extract)

\begin{tabular}{lll}
\hline Normal Tissue & $\mathrm{r}=0.604$ & $\mathrm{p}=0.029$ \\
\hline Tumor Tissue & $\mathrm{r}=0.931$ & $\mathrm{p}<0.001$
\end{tabular}

In the present investigation, we demonstrate for the first time the effects of aqueous extract of Avocado leaf on the activity level of ADA in cancerous and non-cancerous tissues of larynx. ADA which catalyzes the conversion of adenosine to inosine and deoxyadenosine to deoxyinosine, is the key enzyme in purine salvage pathway of mammalian. Due to the irreversibility of the reaction, it is the one of the rate-limiting steps in adenosine degradation (10). Adenosine behaves as an 'alarm' that constitutes various responses to restore tissue homeostasis. In the carcinogenesis process, the increase of adenosine is not a passive product of cancer tissues (13). It not only generates 'an immunosupressed niche' to promote the onset of neoplasia with an angiogenic and matrix remodelling environment but also activates tumor progression and metastasis indirectly (14). In a study with 51 larynx carcinoma cases, it has been reported that ADAR1 mRNA were significantly different inbetween carcinoma, peri-carcinoma and non-carcinoma tissue samples of larynx. Authors stated that ADAR mRNA and therefore ADA enzyme which are expressed broadly in larynx carcinoma tissues may have a substantial role in the development of larynx carcinoma (15). In our study the significant increase of ADA in larynx tumor tissues compared with the noncancerous control tissues is in agreement with the studies that showed high ADA activity in patients with various HNC types (16-18). The studies explicated this increase as a compensatory mechanism against toxic accumulation of its substrates. We think that elevated ADA activity might be also an attempt to supress formation of the immunosupressed niche which promotes the onset of neoplasia and/or to inhibit tumor progression and metastasis. Thus we predicted that a natural agent that alter ADA enzyme activity seems to have possible effect on the carcinogenesis process of SCC of larynx.

In anticancer therapy, ADA is a complex enzyme whose inhibitor and itself are both used. ADA inhibitors like EHNA, Deoxycoformycin are being used for chemotherapeutical purposes for blood derived tumors such as leukemia, lymphoma (19). ADA anticancer therapy is investigational and recommended therapy especially for solid tumors (11). Our results show that Avocado leaf extract activate ADA enzyme in cancerous and non-cancerous tissue of the larynx. The activation in cancerous tissue is higher than non-cancerous tissue of the larynx. It seems possible that reduced adenosine due to the activation of ADA enzyme may play a substantial role on the effect of the Avocado

Adress for correspondence: Sağlı Bilimleri Üniversitesi Ankara Abdurrahman Yurtaslan Onkoloji Eğitim Ve Araştırma Hastanesi Demetevler Yenimahalle 
leaves on the carcinogenesis process in laryngeal tissue. This activation may result from chemical constituents of the Avocado leaf extract.

However there are some limitations of our study as seen in the in vitro studies, since the circumstances in livig cells are different. Our results may lead to preliminary understanding of the subject. We think that the biochemical studies are important in this issue, to show which medicinal plants may have an effect on different types of cancer and to elucidate the molecular mechanisms. In this context, further studies including cell culture and invivo studies are needed to obtain more descriptive informations and to clarify the effectiveness of ADA and Avocado leaf extract in this field.

In conclusion, ADA enzyme activity of the cancerous tissue was found to be increased compared with noncancerous tissues in LC patients. Adenosine which is a tumor promoting substrate in carcinogenesis process, may generate this effect in the onset of neoplasia, progression and metastasis processes (14). Degradation of this substrate is the main outcome of increased ADA enzyme activity and contributes to FORs development. Our results can be explained as elevated ADA enzyme activity is a compensatory mechanism against toxic accumulation of its substrates (adenosine and deoxyadenosine) and Avocado activates ADA actitvity in cancerous tissues higher than non-cancerous tissues of larynx.

\section{Acknowledgement:-}

\section{Declaration of interest statement: None}

\section{Referanslar}

1- Flint PW, Haughey BH, Robbins $\mathrm{KT}$ et al. Otolaryngology-Head and Neck Surgery 6th ed. Mosby, Inc, Philadelphia 2014: 1601-33.

2- Ding $H$, Chin $Y W$, Kinghorn AD, D'ambrosio S. Chemopreventive Characteristics of Avocado Fruit. Semin Cancer Biol. 2007; 17:386-94.

3- Martin-Cordero C, Leon-Gonzalez AJ, CalderonMontano JM, Burgos-Moron E, Lopez-Lazaro M. Pro-oxidant natural products as anticancer agents. Curr Drug Targets. 2012; 13:1006-28.

4- Siu D. Natural products and their role in cancer therapy. Med Oncol. 2001;28:888-900.

5- Kim OK, Murakami A, Takahashi D et al. An avocado constituent, persenone A, suppresses expression of inducible forms of nitric oxide synthase and cyclooxygenase in macrophages, and hydrogen peroxide generation in mouse skin. Biosci Biotechnol Biochem. 2000;64:2504-7.

6- Butt AJ, Roberts CG, Seawright AA et al. A novel plant toxin, persin, with in vivo activity in the mammary gland, induces Bim-dependent apoptosis in human breast cancer cells. Mol Cancer Ther. 2006;5:2300-9.

7- Roberts CG, Gurisik E, Biden TJ, Sutherland RL, Butt AJ. Synergistic cytotoxicity between tamoxifen and the plant toxin persin in human breast cancer cells is dependent on Bim expression and mediated by modulation of ceramide metabolism. Mol Cancer Ther. 2007;6:2777-85.

8- Ding H, Han C, Guo D, Chin YW, Ding Y, Kinghorn AD. Selective induction of apoptosis of human oral cancer cell lines by avocado extracts via a ROS-mediated mechanism. Nutr Cancer. 2009;61:348-56.9- D'Ambrosio SM, Han C, Pan L, Kinghorn AD, Ding H. Aliphatic acetogenin constituents of avocado fruits inhibit human oral cancer cell proliferation by targeting the EGFR/RAS/RAF/MEK/ERK1/2 pathway. Biochem Biophys Res Commun. 2011;409:465-9.

9- Lokshin A, Tatiana R, Huang X, Zacharia LC, Jackson ED, Gorelik E. Adenosine-mediated inhibition of the cytotoxic activity and production by activated natural killer cells. Cancer Res. 2006; 66: 7758-65.

10- U.S. Pat. No.8,741,283 B2. Adenosine deaminase anticancer therapy.

11- Guisti G. Methods of enzymatic analysis Vol 2. Bergmeyer HV Ed. New York: Academic Press; 1974; 1092-9.

12- Antonioli L, Blandizzi C, Pacher, P, Haskó G. Immunity, inflammation and cancer: a leading role for adenosine. Nat Rev Cancer 2013; 13: 842-57.

13- Sitkovsky MV, Kjaergaard J, Lukashev D, Ohta A. Hypoxia-adenosinergic immunosuppression: tumor protection by $\mathrm{T}$ regulatory cells and cancerous tissue hypoxia. Clin. Cancer Res. 2008;14: 5947-52.

14- $\mathrm{Yu} \mathrm{W,} \mathrm{Zhao} \mathrm{Y,} \mathrm{Wang} \mathrm{K,} \mathrm{Dong} \mathrm{M.} \mathrm{Detection} \mathrm{of}$ ADAR1 mRNA expression in larynx carcinoma tissues. Lin Chung Er Bi Yan Hou Tou Jing Wai Ke Za Zhi. 2008 Jan;22(2):73-5.

15- Ashok KJ, Pinto GJO, Kavitha AK, Palathra MJ. The diagnostic and prognostic value of serum adenosine deaminase levels in head and neck cancer. J Clin Diagn Res 2008; 10: 833-7.

16- Kelgandre DC, Pathak J, Patel S, Ingale $P$, Swain N. Adenosine Deaminase-a Novel Diagnostic and Prognostic Biomarker for Oral Squamous Cell Carcinoma. Asian Pac J Cancer Prev. 2016: 17; 1865-8.

17- Ant A, Inal E, Avci A et al. Oxidative stress in relation to adenosine deaminase, nitric oxide, nitric oxide synthase and xanthine oxidase in oral cavity cancer. Eur Res J. [accessed 2017 June 20]:[6 p.] [DOI: 10.18621/eurj.322520].

18- Agarwal, Ram P. Adenosine deaminase. Measurement of activity and use of inhibitors. Methods In Pharmacology 6 (2013): 109-25. 